\title{
体育・スポーツの戦後改革に関する 「第一次米国教育使節団報告書」の作成過程
}

\author{
草 深 直 臣1)

\begin{abstract}
The procedure of making out "The first Educational Mission's reports" on the reform of physical education and sports on post World WarII.
\end{abstract}

Naoomi Kusafuka ${ }^{1}$

\begin{abstract}
The circumstances of physical education and sports in Japan is facing a big change. This change is due to the explosion of people's needs for sports and the idea and the system on post World War revolution.

What are the Idea of physical education and sports? It's obvious that the reform was accomplished by the occupied power.

By grounding the documentation of GHQ/SCAP-Civil Information \& Education Section, the author will approach the process of the establishment on the reform of idea and fundamental framework of physical education and sports in the period of setting up the branch of physical education in Education Division to the completion of Educational Mission's Reports. The author will analize the important two documents: 1) lecture note titled "physical education" by Major Norviel, Officer of the branch of physical education, 2) report-draft by Dr. McCloy, a member of the mission and the professor of Iowa University.
\end{abstract}

Key words: idea, frame-work, reform of post World WarII, Mission reports, documents of GHQ/SCAP-CIE

(Japan J. Phys. Educ. 41: 59-67, July, 1996)

キーワート：キーワート：理念、伜組み、戦後改革,

教育使節団, GHQ 文量

はじめに

既に戦後から半世紀が経ち, 我が国の体育・ス ポーツ状況は，大きく变化しょうとしている。 が，その変化は，様々な曲折を释たにしても，戦 後改革の理念と制度がうみたしたものである.

では，体育・スボーツの戦後改革とは, 自明の ことであろうか？“否”である.

もとより，多くの研究成果がある.たが，体育
・スポーツの戦後改革をトータルな時代史として 捉えるには，先行研究には，共通した大きな弱点 がある。

その 1 つは, 戦後改革が連合国軍による占領 下でなされた改革であるという冷緟な事実によっ ている．連合国を代表する極東委員会と日本占領 を実質的にささえたアメリカ合衆国政府と連合国 軍最高司令官総司令部 (以下, GHQ/SCAP と略 称）の存在を搭象しては, 戦後改革の理念と意志 を解明したことにはならないからである。すよ り，ベールに包まれていた GHQ/SCAP の理念 と意志を明らかにしえなかったのは，史料が末公
1）立命館大学産業社会学部 干603-77 京都府京都市北区等持院北町 56-1
1. Ritsumeikan University, College of Social Sciences, 56-1 Tojiinkita, kita-ku, Kyoto 603-77 
開による時代的制約によるものであった.

いや，たからこそ，米国における情報公開法の 制定によって，連合国関係の史料が公開されたこ との意義をふをえ，体育・スポーツの戦後改革の 全体像にせをることが重要なのである.

本研究は, 体育・スボーツの戦後改革研究の第 一歩として，GHQ/SCAP 特別参謀部の 1 つ民間 情報教育局 (以下，CIE と略称）文書によって7), 「戦後教育改革のバイブル」といわれる第 1 次対 日米国教育使節団報告書（以下，教育使節団と略 称）の作成過程を跡づけながら，体育・スポーツ 分野の改革視点と基本的枠組みを明らかにした い.

\section{1. 占領政策の出発}

1945年 8 月15日,「ポツダム宣言」受諾の詔栜 が発せられ，アメリカ合毷国が中軸となった日本 占領の「究極ノ目的」は，「日本国ガ再ビ米国ノ 脅威トナリ又ハ世界ノ平和オヨビ安全ノ妿威卜ナ ラザルコトヨ確実ニスル」ことであり，そのため の基本原則の一つが, 軍事力の解体と教育の非軍 事化であった。

1945年10月 22 日の GHQ 指令「日本教育制度 二対スル管理政策」によって教育の非軍事化方針 が明確にされるまでに取られた措置は注1)，「ポッ ダム」条項に盛られた「戦時教育」の停止・一掃 に基うくく措膡であるから，その後の政策方針が確 立して執られた措置とは区別をして抢かねばなら ない.

たた，「日本教育制度二対スル管理政策」後, 直ちに「体育の軍国主義的傾向の一掃」の朹組み と内容が，CIE 側にも日本側にも明確になった 訳ではない。例えば，11月 1 日付厚生省体力局 通達「戦後二於ケル体力行政二関スル件」, 11月 6 日付文部省体育局通達「武道ノ取扱二関スル件」 および12月26日の文部省体育局通達「学校体錬 科関係事項ノ処理徹底二関スル件」の間には，武 道の取り扱いについて明らかな相違がある. 厚生 省通達は, 国家武道の持つ戦技的要素を否定しつ つも「国民武道を奖励している」のであり，武道 が全面禁止になるとは思っていなかった18)。
た，11月 6 日付通達では，課外に於ける自主的 な活動が許容される余地を残していたのに対し て，12月26日付通達によって，正課のみならず 課外活動に才いても学校武道が全面禁止されたの は，「全ての学校に於ける日本の軍事的および準 軍事的教育抢よび教練は禁止させる」出との政策 的理由に加えて，他方軍政部における視察基準の 不安定さ・㖟昧さを一掃させるためであった。

また1945年内には，CIE 教育課の機構整備は 十分に進んで抢らず，体育担当官む配備されてい なかった．CIE 教育課が体育・スポーツ政策を 自覚的に追求するのは，1946年 1 月に招聘が決 定された「教育使節団」を迎える準備段階で，日 本教育に打ける体育の比重の大きさに気ついて, 男子教育担当であったノヴィール (NORVIEL) 少佐が，かってカリフォルニア州グランダーレ市 の都市・レクリエーション監督官であった経歴3) をかって，担当させた同年 1 月 20 日以降のこと である.

\section{2. ノヴィールの華備活動}

アメリカ合采国は, 戦時中から, 日本占領の基 本構想を練り，そのための手引書や政策資料を準 備していた．そして，それらのブランやマニュア ル等は，GHQ/SCAP の発足に当たって，そのま ま，引き継がれた，その基本の1つが，1944年 6 月23日付アメリカ陸軍民政部“CIVIL AFFAIR HANDBOOK. JAPAN-Section15. EDUCATION"5)である.

これを基本資料にしながら，教育使節団を迎え るために，ノヴィールは極めて精力的に学校視察 やヒアリングに着手する.

まず，2 月 6 日の胃田区北国民学校をはじめ に, 忍ヶ岡高等女学校, 上野中等学校, 東京第一 師範付属学校, 東京第一師範学校, 東京高等女子 師範学校、東京帝国大学, 自由学園, 東京体育専 門学校, 桜田国民学校, 東京第一師範学校女子 部, 東京第二高等女学校, 東京文理科大学, 東京 高等師範学校, 都立高等学校と，3 週間で15校を 視察している.そして，これらの学校視察を通し て，彼は以下のような学校体育についての感想を 
述べている注2)。

(1) 東京体育専門学校について, 学生のリーテ ングへの関心はかなり多様だが，体育・スポーツ への関心は，かなり高い。体育活動の学級学畾は 十分に練られていた。

(2) 全体を通じてこれらの学校で，関心度の高 い模範授業が行われているからといっても，決し て驚くべきことではない，日本人は，かなり高い 資質をむっている. 日本的な修正・変容がいくつ か見られたけれど，西洋スポーツは優势である.

教師も子供の態度も，東京高等女子師範学校のバ スケットのトレーニングを除いては，十分に健全 である。これらの授業でみられたフフレイ精神やリ ラクゼーションは，取るに足りない，見せかけの ものでは決してない.

(3) たた，高等女子師範学校の授業は、スポー ツの基本的目的を减退させてしまうものた。.

ここにみられる「西洋スポーツ」を受容した体 育授業への高い評価が，「我々は体育において， 日本の前進は可能であると信じる.その組織には 多くの長所があり，その人的要素は西洋諸国と比 ベても見劣りしない」と教育使節団報告書が評価 した源泉になっている.たた，視察した学校が， 当時の日本でも先進的な模範校であることを割り 引いて評価しておく必要があろう.

また視察と平行して，ノヴィールは，日本体育 ・スポーツ界の主だった人物にも想談し, 聴取を 積み重ねた注3)。これらの懇談について，ノヴィ 一ルは次のような要䄪を 3 月 7 日に教育課長に レポートしている.

(1) 文部省役人達との会議で, 日本体育の歴史 や体育計画の像がかなりはっきりした.

(2) 大日本体育会の末弘達との会議で, 日本の 体育・スポーツの歴史について軍閥に圧迫された と言う熟虑すべき情報を得た。

(3) 記者達から，スポーツ組織と人材について かなり価値ある情報と意見を得た。

(4) 南原東京帝大総長との摡談において, 南原 は「とんな年跲でも，また生活のいかなる場所で む男女とともにスポーツに参加する機会が払張さ れるべき」であるのに，「大学での基金・リーダ
ーシップ・用具は全く不適切である」と述べた。 これに，ノヴィールは賛意を表しながら，「上り 多くの学生がスボーツへ参加するための予算をど うすべきかを尋ねたのに対して，南原は「野球 のように一人の選手のスキルに注意を払うのでは なくて，もっと集団の民主的な行動に重点を膡く スポーツを，要好させる必要があり」、「スポーツ は，日本の民主主義を促進する手段の一つである と信じている」と強調した.

末弘厳太郎大日本体育会副会長達との会談内容 の詳細は明確ではないが，少なくとも，大日本体 育協会が官製団体「大日本体育会」に改組転換さ れたのは，軍閥によるものであり，1945年10月 に大日本体育会は政府の統制から離れて民間団体 になったのであるから，太平洋戦争時の性格とは 違うと説明したことは, 推察に難くない.

また，日本側教育委員会の委員辰であり，リベ ラリストである南原の意見に耳を傾け，そのう え, 大学視察を通じて, 選手に偏重してきた日本 スボーツの歪みを是正するために，大学体育の充 実を痛感したノウィールとの問答は，大学正課体 育の源流を探る上で興味深い。

\section{CIE 小冊子「日本の教育」と講莪録 「日本の体㕕」の概要と特徵}

以上の視察と锠談を経て，完成したのが， CIE「日本の教育」)とこれを補足する講義録「日 本の体育」13) である.

「日本の教育」は，「教育使節団団員および地方 軍政部教育担当官」への適切なブリーフィングの ための資料として，主に教育課員フィッシャー (FISCHER) ・ ワンダーリック (WANDER-

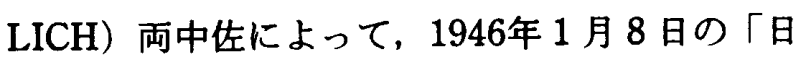
本の教育制度の管理と統制一試案パンフ」を補足 ・改訂したものである17).

「日本の教育」は，「第 I 部日本の教育制度（昭 和 20 年 8 月 15 日以前)」と「第I部連合国軍によ る日本の教育管理」から構成され，「連合国軍が 日本帝国政府に発した教育指令」掞よび「日本の 教育資料」が，付録としてつけられている.

体育については，学校制度を中心に以下のよう 
に概観している.

「1871年，全国的な学校制度が組織されたと き，軍人によってオランダ式をモデルにした体操 が導入され，軍隊教育と学校教育が導入され，」 「1902年，体操はオランダ方式からスウェーデン 方式に取って代わり，本格的な体育がここに始を った.」「1913年に，文部省に体育課が設膡され， 各学校が体育計画を立てる際，一律に行うように 『学校体操教授要目』を交付したが，各体育指導 員による多少の解釈の相違は許された。この要目 には体操・遊戱・競技の3 側面が述べられてい る.」「1920年以前は，体育は資格を特別に認定 された男性が指導・管理にあたっていたが，これ らのなかには，スポーツマンシップや体育に関す る特別な資格や経験を持たない退役軍人がしばし ば当てられた，体育教育を受けたものが退役軍人 にとって代わり広く活躍するようになったのは， 1920年頃になってからである.」「1925年から， 中等学校以上の学校に現役の陸軍将校が配属さ れ，教練の责任を持つことになった，配属将校は 体育教育となんら尃門的なつながりを持っていな かったが，実際には，教練と同様に体育教育にも 極めて大きな影韫を及ほした。」「1942年文部省 は，体育の教授要目を改訂し，体操・武道・およ び戦技訓練を加えた.」「対米戦争が始まると軍は 西洋的な体育全てを排除しようとし，その圧力は 非常に大きなものであった，その結果，学校から 西洋的なスポーツは殆ど消えていった．スポーツ 用具はあっと言うまに戦争用に供され，スポーツ や競技のルール・ブックは焼き塔てられ，以前は 運動場として使われていた土地の約 $2 / 3$ はいまや 野菜畑になってしまった，戦争が進むにつれ，教 練だけに重点が置かれ，他の体育訓練は二義的な むのになってしまった．教練は実際の戦場にいる ような夜戦演習を含む戦闕的なむのになった。 ス ポーツとしてその形を残しているものでさえ，軍 国主義的な趣を帯びてきた．生徒は砲丸投げの代 わりに手榴弾を投げ，ランニングの多くは装備を 背負って行うようになり，水泳は鉄砲と荷を背負 って泳がされた。『墄私奉公』というスローガン は天皇の意志に従うことを意味するだけでなく，
最高の美徳としての名誉ある死の称賛をも意味し て抢り，当局はこれを極めて有効に使ったのであ る.」

講義録「日本の体育」は，「教育使節団」に対 して CIE 教育課員が抢こなった一連の分野別オ リエンテーションの際に使用されたもので，「序」 「学校体育ブログラム」「学校衛生プログラム」「健 康・体育・レクリエーション団体」「一般のスポ 一ツ大会」「結論」から構成されている.

ノヴィールは，この講義録を使って，3 月14日 の午前 9 時から45分ほどの説明をおこなっ た6,16,17)

胃頭，ノヴィールは「体育・スポーツのプログ ラムが，日本においてリーダーシップと民主主義 の発展のために，重要な機会の一つを提供するむ のと確信する」と表明し，報告の制約を断りなが らも，学校体育分野の「再教育の原則的問題」に ついて，以下の11項目にわたって指摘した.

(1)軍国主義的教育と訓練を除去する事と並んで 政策や専門用語の明確化，(2)新しい政策に沿う体 育目的と目標の再検討，(3)目的・目標と並んで身 体訓練内容の再検討, (4)達成を評価するテストプ ログラムの改訂，(5)マニュアルの改訂，(6)身体訓 練やスポーツを通じて民主主義を発展させていく 担い手としての教員再教育，(7)文部省と学生競技 組織との関係の検討, (8)文部省と大日本体育会と の関係の検討，(9)野球に関する法令の改訂，(10競 技会での入場料と税金に関する法令の改訂(11形式 主義や単調さからの身体訓練の解放.

また，スボーツについては，「異常な勝利欲は 日本人の国民性である」「スポーツ科学研究が発 展したこと」「日本人の衝動, 自己㬢牲, 勝利へ の決意がみられること」「軍国主義者により他国 民にたいする日本人の優越性の宣伝に利用され た」と，戦前の特徵を説明するとともに，スポー ツ活動や大会状況について，以下のような問題点 を指摘した。

「日本はスポーツへの参加を求める偉大な国で あった．しかし，実際はその反対であった。現実 にはプロフェッショナルと英雄崇洋の国である。 大会への参加者はスポーツに秀で，自己の技能の 
完成に向けて果敢に専心する男性たけである，他 方，日本人の大多数は殆ど注目されていないか， 又は中学校以上の身体訓練を受けていないのであ る.」 そして，「結び」として，以下のような見通し と課題を明らかにした.

(1) 未解決な問題. 専門家によって注意深く研 究されなければならない多くの未解決な問題があ る. 男子体育, 女子体育, 健康教育、レクリエー ションの専門家は，日本の体育・レクリエーショ ン計画の再建に価値ある貢献をなすことが出来よ う.

(2) 体育マニュアルの改訂.これらの手引きの 改訂は，重要である。しかし，それらは全体の体 育プログラムの慎重な研究が完遂されるまでは, 適当に改訂することは出来ない。

(3) 靴と運動用具. 日本は現在, 日本の民主化 に大いに貢献するであろうスポーツの大いなる復 興をなそうとしているが, 用具の充実なしには達 成できない，

翌15日に，教育使節団一行は東京の学校を視 察したが，体育の模範授業が教材別（剣道，柔 道, 銃剣道, 䓡刀, 清㧹運動, 音楽と訓練, リズ ミカルダンス, 徒手体操, 転回運動, ボールゲー 厶) に, 市ヶ谷小学校, 東京第一高等学校, 東京 体育専門学校, 府立第五高等女学校, 東京女子高 等師範学校, 京北国民学校, 府立第六中学校の教 師及び生徒によって夷施され，その特徵と問題点 がヴェールによって説明された。

この講義録「日本の体育」は，ノヴェール自身 が明らかにしているように，情報分析が不十分な 為に極めて初歩的な，概括的なむのである.

たか，「日本の教育」や「日本の体育」に示さ れた歴史認識は，1946年 7 月に完成する特別レ ポート「日本の体育・スポーツの歴史」少なで一 貫している，つまり，1913年の体操・遊戱・競 技から構成されている「学校体操教授要目」をか なりなまでに正当化し，これ以降の体育の歴史を 「被害者」の立場として描いているのである。言 い換えれば，体育の軍事化への従属過程を，「陸 軍現役将校配属令」の施行過程と捉えて，その元
凶を軍部に求めているのである。また，スボーツ む「軍国主義者により他国民にたいする日本人の 優越性の宣后に利用された」と「被害者」に位置 付けられている。

これは，ノヴィール或いは特別レポートを担当 したフォスター（Foster）女史の歴史観がなせる むのというより，彼らが依执した文献史料やヒア リングした情報の所以と言わねばならないたろ う. 例えば, 特別レポート「日本の体育と入ポー ッの歴史」には, 真行寺朗生「近代日本体育史」, 二宮文衛門「体育全史」がかなり引用されている し，また，特別レポート作成に協力した今村嘉雄 ·大谷武一の体育史観か反映してもいる.

それは，兵式体操を排した「学校体操教授要目」 を是とし，それからの逸脱と変容を軍部による王 迫と被害の過程とした歴史観である。従って、こ こから導き出されるのは，体育・スボーツの内部 構造にあで達した天皇制軍国主義の諸要素を摘出 することではなくて，少なくとむ軍事色の排除や 画一主義の一掃を形式のうえで徹底し，「アメリ カン・デモクラシーを体現するスポーツ」の振興 をもってすれば，日本の体育・人ポーツの，ひい ては日本の民主化は可能であるという構図にな る. 後に,「スポーツ=民主主義」という，牧歌 的な受け止めが生なれる素地は，ここにある。

\section{4. マックロイ博士の「報告音草案」}

これらの説明と視察を受けて, 教育使節団一行 は3月16日から19日まで, 奈良・京都の視察に 出かけた後, 3月21日から23日にかけて, 教育使 節団員は，各委員会において，報告書作成作業に 従事した。 その際，3月24日の第一委員会におい て討議されたのが，マックロイ（McCloy）博士 が提出した草案「体育」10)である.

この全文は，別稿13)で紹介されているので， ここでは，重要な点だけに触れておく．

草案は「緒言」「現在の状況」「勧告」から成っ ている。

マックロイは，冒頭「日本においては，体育は 国家的教育政策と関連して，学校に抢いてのみそ の機能を果たすという考えはさけねばならない。 
学校は部分的には卒業後の生活を送るための身体 訓練とレクリエーションを準備すべきであり，ま た，地域や家庭教育の組織化によって補足され， 全ての家庭に利用可能なように学校制度によって 組織され促進されなければならない.」と，今日 的には「生涯スポーツ」とも言うべき「国民総体 育」構想を目指した「家庭・学校・地域」の一体 的組織化・計画化を重視している.

その上で，12項目にわたる钦告を記している か，重要な事項は以下の通りである.

(1)「文部省体育局の機能は，支配的で敩格な 統制を行うものから指導的, 助言的, 補足的なむ のへなるべきである．様々な教育機関の教師と行 政官には究極的な向上の自由が保障されるべきこ とが重要である.」

(2)「戦争钼念と結びつく運動の禁止と徒手体 操の非軍国主義的方法での教授に加えて，フェン シング以上に䓡刀や剣道は現在の学校ブログラム には適切ではないと考える，弓道は基本的には䦚 争と言うより儀式である.ささらにそれは中高政者 のための優れた生涯スポーツである. 従って, こ の久ポーツは復活されるべきことを勧告する. （中略）柔道はより肉薄戦型のものについては学 校では禁じられるべきである，が，レスリング型 の柔道は，真に日本のナショナルスポーツであ る.この形態の柔道は学校で許可されるべきで, 民主主義の理念と調和しない伀統的な慣習のむと にある柔道を修正するために，柔道と教育の双方 の指導者の会議を開催することを勧告する.」

(3)「必修体育は, 初等・中等・高等学校にお いて継続し，大学においても制度化すること.」

(6)「新しい教師用指尊畫が委員会の官僚的支 配の一掃を確保するために文部省以外の議長の指 導のもとに教師委員会によって準備されることを 勧告する. 従って，優れた教材が現れるにつれて 定期的な改訂を行う教授用指導書に関する常設委 員会が設置されるべきである.」

(7)「様々な種類の救材の適応と身体スキルの 教授方法を理解する事に加えて，活動ブログラム を通して望をしい民主的・社会的・個人的態度と 活動習慣を体得させる方法が特に強調されるべき
である.」

(10)「公立学校制度の中に，成人教育ブログラ ムと家庭運動指尊のプログラムを加えることを強 く勃告する．小学校 5 年生から，継繶して生徒 を家庭運動・スボーツ・ゲームの简単な方法で訓 練すること. そのために，リクリエーションやス ボーツ団体と協力してa)生徒自身の『家庭の体 育の先生になろう』運動, b)隣組を通したた恒久 的組織と協力して広籁な運動・フォーラム・実演 を計画すること、また，プログラムでは，年柃と 性差, 個人の興味に対応できる家庭での運動の多 様な形態が強調されるべきである.さらに, 家庭 や行き止まりの路地で行う調整的な価值あるスポ 一ツやゲームを発展させるために男女共同の遊战 に改良すべきである．用具は安価なむので日本の 家庭に付いている小さな庭の広さで行うことが出 来，また家の中でも遊べるのとする.」

(11)「競技は用具が利用できるようになり次第, 学励され，また，日本は国際大会への再加盟を奖 励・承認されることを钬告する.」

(13)「教員養成課程に打いては，生徒のニーズ と地域への状況への適応が特に強調されるべきで ある. 地域の教員組織は自らの討論之集団実践を 奖励されるべきである.」

(15)「日本の専門的体育団体はその活動を一新 すべきであり，また，政府機网の支配から決別す ベきである．同様なことが，軍国主義的でないス ポーツ団体にもなされなければならない.」

これらの勧告の趣旨と項目の多くは，2 項の 「武道関連」および11項目の「スポーツ競技の国 際復帰」を除いて, 報告書の「体育の項目」以外 にも，内容として盛り込まれていった。

\section{5. まとめにかえて}

いずれにせよ，天皇制軍国主義体制の重要な支 柱の一つである官僚機構が殆ど無俉なまま温存さ れ、また、スポーツ関保諸団体・組瀻が政府の直 接支配から民間的装いに改末ったことをむって， これらに大きな期待を込めて，日本の民主化と体 育・スポーツの将来展望を託したのが，「教育使 節団報告書」であった。 
そこには，一面,「スポーツ＝民主主義」と言 う牧歌的な罒式が浮かんでくる。しかし，果たし て，それだけであろうか？

1946年 3 月 21 日に「南原繁東京帝国大学総長 並びに日本側教育家委員会委員長から G. D. スト ダード米国教育使節団団長に提出された特別報告 書」12) と比較してみると，問題が明瞭になる.

「特別報告書」は，「身体的教育の側面として， 戦時中のような訓練を廃止すべきである.たとえ ば，軍事訓練でなされたような英雄主義のような むのである. 特殊な訓練以上に重要なのは, 人的 作為・不自然さが小学校以上のすへてての体育訓練 に漫透していること」であり，このための改革は 「身体を向上さすような平静かつ陽気な活動を堅 苦しく，機械的で画一的なむののかわりとし，公 明正大なプレイと競争の原理を導入し，他人を尊 敬し，堅苦しい適合よりも，子どもや青少年の中 にある自然の力による, 自由と自発性による」と するに止まっている.

特別報告書むスポーツの導入を示唆している. しかし、それは学校教育の方法レベルでしか捉え られていないのである.

これに対して，教育使節団報告書のペースにあ る講義録「日本の体育」やマックロイ草案「体育」 を重就わせてると, 改革の重要な視点と方向 か読み取れる.

第 1 に，学校体育活動の現状について，文部 省通達による「軍事色の一掃」がもたらした正課 授業について、「悪くないブログラム」との評価 を与えているか，それは飽くまで過渡的な措置と しての配度である.ただ、「新教師用参考書の起 草を企てる常設員会」の設置を勧告したにせよ， その具体的な方向が示されているわけではなく， むしろ,「体育マニュアルの改訂」には相当の困 難を予想し，慎重で十全な㛟討の必要性を見通し ている.

第 2 に, 南原東大総長との琶談でも同えたよ うに, 大学体育・スボーツにはスタッフむフロク ラムもないことを指摘し，これに対して文部省む 充実の方向で解決する意向を当初より示してい た.それがマックロイの勧告になって、「報告書」
にも盛り込まれたのであり，この意味で，大学必 修体育は，体育の国民的普及を目指す改革構想の 一環として，日米合作の措置であるといえよう。

第 3 に, 学校課外活動にとられた学校報国団 の改組措圆については，「生徒の自由な自主性を 重んじるむの」として見ていると共に「スポーツ 活動は，生徒達の良い面を引出し,リーダーシッ プを身につける機会を提供するばかりでなく，身 体の健康に価値ある貢献をする構成要素になって いる」と高い評価をあたえており, 改革の土锤と して大きな期待をかけている.

第4に，しかし，文部省報告によりながら， 体育・スポーツ活動に不可欠な施設・用具の深刻 な事態, 指導性の欠如が強調されている.「ルー ル・ブックの必要」が文部省報告にみられるの は, 当時においては, スポーツゲームは学校体有 の主流ではなく、これを知っている教師がきわめ て少なかったからである.このために，現職教員 の再研修（武道教員資格の廃止に伴う資格切り替 えを含んで）が最重点課題の一つであった.

第 5 K, むっとも深刻な事態は施設・用具, とくに用具生産供給の絶対量の不足であり, 理念 実現にとって大きな障害となっているばかりでは なく、ここに用具不足にも対応できる簡便なゲー 么の考案がなされていく、このことは，マックロ イの「公立学校制度の中に, 成人教育プログラム と家庭運動指導のプログラムを加えることを強く 勧告する.」という事項が捨象されて,「家庭運動 の重視」や「用具は安価なむので日本の家庭に付 いている小さな庭の広さで行うことが出来, また 家の中でも遊へるもの」という側面だけが強調さ れることによって, 後に「体育の生活化」の現実 適応的内容を促進する誘因の 1 つになっている.

第 6 K，政府の束縛から解放された民間諸団 体については，政府との関係で補助金への制限が 問題提起されている. まさに，スポーツ大国日本 の実態が，スポーツの国民的普及によっているの かと疑問を呈し，「実際に日本は尃門家とヒーロ 一崇洋の国である」と批判して扔り，スポーツ団 体の財界や政府への依存体質を克服する上で不可 欠な大采的支持基盤の抝大を展望している，この 
見通しこそ「清瀬構想」と言われる「スボーツ の大采化」理念の源泉である.

以上の脈絡で見るならば，改革の方向は，学校 体育のスポーツ化という単純なむのではなかった といえよう。それは，勝利至上主義を排しなが ら，体育・スポーツの住民自治による地域的発展 を目指し，その核に学校を位膡付け，スボーツを 学習することを通して獾得される諸能力と規範に よって，日本民主化の担い手の育成を構想したの である.

本研究では, 教育使節団報告書の準備過程を, ノヴィール少佐の活動記録，「日本の体育」，マッ クロイ博士の草案を中心に分析することを通じ て，使節団報告書の根底にある基本的視点や方向 を明らかにした。 もとより，占領初期においては 問題は多岐にわたり，事態の解決は複雑である。

このため，日本側の対応や占領軍当局との力関係 は，必ずしも明確には成しえなかった。

しかし，教育使節団報告書の記述だけでなく， その準備過程を探ることによって, 改革の全体像 に迫る端緒になりえよう。

引き䌇き，CIE文書を手がかりに，何を対象 にし，どのように，とんな手順で改革しようとし たか，またどのような矛盾・対抗関係から立案さ れていくのか等を，具体的計画文畫の分析を通じ て，全容の解明に迫ることを課題としたい．

\section{注}

注1） $1945 \cdot 8 \cdot 24$ 発動20号「学徒軍事教育立戦時体 鍊及学校防空関係諸訓令等/措圈二関スル件」, $1945 \cdot 9 \cdot 19$ 官体 47 号「武器引渡シ命令二対ス ル学徒教娻用銃兵器処理二関スル件」, $1945 \cdot 10$ . 3 発体67号「時局ノ急枟二伴ウ学校教育二関スル 件」並びに「学徒ノ軍事教育二関スル件」等の一 連の通達. 文部省（1946）釉戦事務処理提要第一 巻所收 : 東京.

注2）ノウィールの会護報告による引用は，Major Norviel "Conference Report" (BOX No 5734, File\#1) 及び “Weekly Report”" (BOX No 5728, File\#3) に よる. National Archives-Washinton national Reference Center. (WNRC) 以下,「会議報告」週報告」 については日付けのみを記し，注を省く。

注3）この間の㤍談者は，次の通り。(2・1-7) (1)栗本
義彦（運動振興棵長）北沢清（体育課長）松本浩

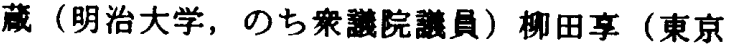
YMCA 体育主事)，(2)二ューゼント中佐 (CIE 教 育課長，のち局长），(3)南原繁（東京帝大総長） $(2 \cdot 15)$ ，(4)末弘诶太郎，清瀬三郎，渡辺和孝（い ずれも大日本体育会） $(2 \cdot 18)$, (5)平沼亮三（前大 日本体育会会長）(2.21)，(6)笠原道生（前厚生 省体育局長)，(3・1-7）(7)村山保（ニッボンタイム ズ）加納克明，坂本三郎（朝日新聞），(8)白山源三 郎 (大日本厚生会).

\section{文献}

1) CIE. Education Division; Education in Japan (15 February 1946)，児玉三夫訳（1983）『日本の教 育」. 明星大学出版部 : 東京.

2) CIE. Education Division. Research Units; Special Report $\langle 121-\mathrm{RM}-\mathrm{C}\rangle$ The History of Physical Education and Sports in Japan. (29, July, 1946). BOX No 5441, File\#3. WNRC.

3) CIE. Education Division; Edcation Division Organization and Function. Trainor Papers, BOX No 43. Stanford University. Hoober Institute.

4) GHQ/SCAP (1947); Administration of the Educational System of Japan（文部大臣官房文書課 『終 戦教育事務処理提要」第 1 輯所収，東京).

5) Kodama, Mituo Edi. (1983) Educational Documents of Occupation Japan voll, Meisei University Press: Tokyo.

6) 久保義三(1984)『対日占領政策と戦後教育改革」. 三省堂 : 東京.

7）草梁直臣（1983）「資料䊅介，C.I.E. 体育担当官 覚書にみる戦後初期の保健・体有・レクリエーシ ョン計画の総括と裸題」. 立命館大学保健・体育 研究第 2 号.

8) 草深直臣 (1987)「体育・スポーツの戦争改革」『ス ポーツの自由と現代下巻」. 青木害店 : 東京.

9）草潹直臣（1992）「戦後改革に貢献したアメリカ 人」.『スポーツ科学と人間」. 立命館経済学会: 京都.

10) McCloy, Charles, H. (1946) PHYSICAL EDUCATION, Papers, McCloy Special Collection. BOX No 5, Folder\#9. University of Iowa Library.

12）日本側教育委員会（1946）米国教育使節団に協 力すべき日本側教育委員会の報告畫. 国立教育研 究所戦後教育資料集.

13) Norviel, William: Physical Education in Japan (13 March 1946), BOX No 5439, File\#12. WNRC.

14）小川利夫・新海英行稨（1990）『GHQ の社会教 
育政策一成立と展開一」. 大空社 : 東京.

15）新野 守・草深直臣（1991）「第一次米国教育使 節団報告書」に抢けるC. H. マックロイの役割. 立命館教育科学研究第 1 号.

16）鈴木英一（1983）『日本占領と教育改革」. 怔草書 房 : 東京.

17）土持ゲーリー法一（1991）『米国教育使節団の研
究」.玉川大学出版部 : 東京.

18）渡边一郎編（1981）大日本武徳会の設立とその 解散一近代武道史研究資料 II. 筑波大学体育科学 系.

平成 7 年 8 月 11 日受付 平成 8 年 4 月 26 日受理 